Dragan Kalaba

zamenik višeg javnog tužioca u Čačku

\title{
KRIVIČNO DELO NASILNIČKO PONAŠANJE NA SPORTSKOJ PRIREDBI* - Zakonodavstvo, sudska praksa, dileme -
}

„Veliki sportski događaji su potencijalna mogućnost ozbiljnog narušavanja javnog reda i mira i eskalacije nasilja, uvek praćenog uništavanjem imovine, pa i lakšim i teškim telesnim povredama, a ponekad i smrću. Ovaj oblik nasilja najizraženiji je na fudbalskim utakmicama i u sociologiji sporta je poznat kao fudbalski huliganizam."

Krivično delo nasilničko ponašanje na sportskoj priredbi u svom osnovnom obliku - čl. 344A st. 1. KZ (Službeni glasnik RS 72/09 a koji je stupio na snagu 1. 9. 2009. god.) glasi: „Ko neovlašćeno uđe na sportski teren ili deo gledališta namenjen protivničkim navijačima i izazove nasilje, fizički napadne ili se fizički obračuna sa učesnicima sportske priredbe, vrši nasilje prilikom dolaska ili odlaska sa sportske priredbe, unese u sportski objekat ili baca na sportski teren ili među gledaoce predmete, pirotehnička sredstva ili druge eksplozivne, zapaljive ili škodljive supstance koje mogu da izazovu telesne povrede ili ugroze zdravlje učesnika sportske priredbe, oštećuje sportski objekat, njegovu opremu, uređaje i instalacije, svojim ponašanjem ili parolama na sportskoj priredbi izaziva nacionalnu, rasnu i versku mržnju ili netrpeljivost usled čega dođe do nasilja ili fizičkog obračuna sa učesnicima sportske priredbe”.

${ }^{*}$ Rad primljen: 03. 11. 2010.

${ }^{1}$ Mr Božidar Otašević: Fudbalski huliganizam u praksi i zakonodavstvu Srbije, Izbor sudske prakse, br. 10/09, str. 11 . 
U čl. 189. KZ - prelazne i završne odredbe i to u tački 3. predviđeno je da danom stupanja na snagu ovog zakona, prestaje da važi čl. 20. Zakona o sprečavanju nasilja i nedoličnog ponašanja na sportskim priredbama (Službeni glasnik RS 67/03, 101/05 i 90/07).

Ovakav sadržaj KZ - biće osnovnog krivičnog dela i citirane prelazne i završne odredbe, nameće pitanje odnosa glavnog i sporednog krivičnog zakonodavstva. Glavno ili osnovno krivično zakonodavstvo obuhvata krivično-pravne odredbe sadržane u Krivičnom zakoniku, dakle radi se o zakonodavnom aktu koji sadrži isključivo krivično-pravnu materiju. To je upravo sadašnji Krivični zakonik koji je stupio na snagu 1. 1. 2006. g. i njegove izmene i dopune. Sporedno krivično zakonodavstvo predstavlja krivično-pravne odredbe sadržane u vankrivičnim zakonima koji regulišu druge oblasti (privreda, zdravstvo, poreski sistem, izgradnja objekata i dr.). U čl. 13. KZ „važenje opšteg dela ovog zakonika" je predviđeno da odredbe opšteg dela ovog zakonika važe za sva krivična dela određena ovim zakonikom ili drugim zakonima. To dalje znači, a što proizilazi iz prethodne odredbe, da u našem krivično-pravnom sistemu i dalje važi podela na glavno i sporedno krivično zakonodavstvo i da smo još daleko od unifikacije krivičnog zakonodavstva.

Upravo brojni događaji, neredi i sukobi, posebno na fudbalskim stadionima su „naterali” zakonodavne organe Srbije da reaguju na adekvatan način tako što će se na jednom mestu regulisati ponašanje učesnika sportskih priredbi, a takođe i da se predvide krivična dela i prekršaji protiv javnog reda i mira. Zbog navedenog, donet je Zakon o sprečavanju nasilja i nedoličnog ponašanja na sportskim priredbama koji je objavljen u Službenom glasniku RS br. 61. od 1. 7. 2003. g., a koji predstavlja prvi zakon te vrste donet u Srbiji, kojim se ova materija reguliše na jednom mestu. Navedeni osnovni Zakon je menjan i dopunjavan više puta, o čemu će ovde posebno biti reči, ali je bitno ukazati da je sadašnjim Krivičnim zakonom koji je stupio na snagu 11. 9. 2009. g., prestalo da važi samo krivično delo predviđeno u čl. 20. ranije citiranog Zakona o sprečavanju nasilja..., a prilikom obrade krivičnog dela iz čl. 344a KZ, za pomoć služe sve ostale odredbe Zakona o sprečavanju nasilja i nedoličnog ponašanja na sportskim priredbama.

Kako biće osnovnog krivičnog dela iz čl. 344a st. 1. KZ sadrži elemente kao npr.: sportski teren, gledalište, učesnik sportske priredbe, sportska priredba, sportski objekat, sportski teren, to se za njihovo razumevanje, tumačenje, imaju koristiti sve ostale odredbe Zakona o sprečavanju nasilja i nedoličnog ponašanja na sportskim priredbama.

Član 20. Zakona o sprečavanju nasilja i nedoličnog ponašanja na sportskim priredbama predviđa krivično delo nasilničko ponašanje na sportskoj priredbi i glasi: „Ko u nameri da izazove nasilje uđe na sportski teren ili 
ulaskom u sportski teren izazove nasilje, fizički napadne na učesnike sportske priredbe, unese u sportski objekat ili baca na sportski teren ili među gledaoce predmete, pirotehnička sredstva ili druge eksplozivne, zapaljive ili škodljive supstance koji mogu da izazovu telesne povrede ili ugroze zdravlje učesnika sportske priredbe ili učestvuje u fizičkom obračunu na sportskoj priredbi”.

Zakon o izmenama Zakona kojima su određene novčane kazne za privredne prestupe i prekršaje (Službeni glasnik RS br. 101 od 21. 11. 2006. g. u čl. 5. predviđa izmene navedenih iznosa regulisanih u Zakonu o sprečavanju nasilja i nedoličnog ponašanja na sportskim priredbama. To znači da u pomenutom Zakonu o izmenama, krivično delo „nasilničko ponašanje na sportskoj priredbi i čl. 20." nije menjan ni dopunjavan. Zakonom o izmenama i dopunama Zakona o sprečavanju nasilja i nedoličnog ponašanja na sportskim priredbama (Službeni glasnik RS br. 90 od 1. 10. 2007. g.) u čl. 7. je predviđeno da se čl. 20. - krivično delo nasilničko ponašanje na sportskoj priredbi menja tako da glasi: „Ko neovlašćeno uđe na sportski teren ili ulaskom na sportski teren ili deo gledališta namenjen protivničkim navijačima izazove nasilje, fizički napadne ili se fizički obračuna sa učesnicima sportske priredbe, vrši nasilje prilikom dolaska ili odlaska sa sportske priredbe, unese u sportski objekat ili baca na sportski teren ili među gledaoce predmete, pirotehnička sredstva ili druge eksplozivne, zapaljive ili škodljive supstance koje mogu da izazovu telesne povrede ili ugroze zdravlje učesnika sportske priredbe, oštećuje sportski objekat, njegovu opremu, uređaje i instalacije, ko svojim ponašanjem ili parolama na sportskoj priredbi izaziva nacionalnu, rasnu i versku mržnju ili netrpeljivost usleg čega dođe do nasilja ili fizičkog obračuna sa učesnicima sportske priredbe".

Zakon o izmenama i dopunama Zakona o sprečavanju nasilja i nedoličnog ponašanja na sportskim priredbama (Službeni glasnik RS br. 11 od 29. 12. 2009. g.) ne predviđa izmene i dopune prethodno citiranog čl. 20. u kojem je predviđeno krivično delo nasilničko ponašanje na sportskoj priredbi.

Ako pogledamo radnje izvršenja krivičnog dela iz čl. 20., uočljivo je da u periodu od 2003. g. do 2007. g. osnovno krivično delo je „ko u nameri da izazove nasilje, uđe....", a to je značilo da se ,poseban umišljaj” morao dokazivati, a što je u praksi predstavljalo „određene poteškoće”. Izmenama i dopunama citiranog zakona iz 2007. g. izbačena je „namera”, već je navedeno „ko neovlašćeno uđe na sportski teren...” Ova izmena ima pored zakonodavnih objašnjenja i jedno logično, a to je, šta ko drugi osim učesnika sportske priredbe ima da traži na sportskom terenu, a time je i dokazivanje učinjenog krivičnog dela jasnije i lakše.

Krivično delo iz čl. 344a st. 1. KZ u pogledu radnje izvršenja je adekvatno isto sa izmenama citiranog Zakona o sprečavanju... iz 2007. god. samo što 
u sadašnjem KZ nije više predviđena radnja izvršenja u vidu ,ulaska u sportski teren”. Radnje izvršenja krivičnog dela iz čl. 344a st. 1. KZ su alternativno predviđene i svako može učiniti navedeno krivično delo.

Predmet ovog stručnog rada nije analiza svake alternativno predviđene radnje izvršenja krivičnog dela, jer za to nema potrebe, već kako je prethodno navedeno imaju se koristiti, radi razjašnjenja i preciznosti, ostale odredbe Zakona o sprečavanju nasilja i nedoličnog ponašanja na sportskim priredbama, kao i opšte odredbe Krivičnog zakonika u pogledu primene instituta krivičnog prava.

Kada je reč o nadležnosti sudova, Zakonom o izmenama i dopunama Zakona o uređenju sudova (Službeni glasnik RS 104/09), a u čl. 4. je predviđeno da se u čl. 23. st. 1. tačka 2. Osnovnog zakona dodaju i ,nasilničko ponašanje na sportskoj priredbi", a to znači da za pomenuto krivično delo u prvom stepenu je nadležan Viši sud. Iznećemo nekoliko karakterističnih primera iz sudske prakse:

- Presudom prvostepenog suda okrivljeni je oglašen krivim zbog kriv. dela iz čl. 20. st. 1. Zakona o sprečavanju nasilja i nedoličnog ponašanja na sportskim priredbama, a presudom drugostepenog suda odbijena je kao neosnovana žalba branioca okrivljenog, a presuda prvostepenog suda se potvrđuje.

- Dokazima izvedenim na glavnom pretresu je utvrđeno da je nakon prekida fudbalske utakmice došlo do fizičkog napada na sudiju kome je tada naneta laka telesna povreda i da je to upravo izvršio okrivljeni.

- U svakom slučaju za kvalifikaciju dela o odredbi čl. 20. st. 1. navedenog zakona nije potrebno da je nekom licu naneta telesna povreda već je dovoljno da je takvo lice fizički napadnuto, pa je u konkretnom slučaju za postojanje dela u odnosu na okrivljenog dovoljno da je učestvovao u fizičkom napadu na oštećenog, čak i pod uslovom da u prvostepenom postupku nije dokazano da je okrivljeni naneo oštećenom telesnu povredu. Međutim, iz utvrđenog činjeničnog stanja u prvostepenoj presudi jasno proizilazi da je okrivljeni ne samo učestvovao u napadima oštećenog, već mu je zadao udarac usled kojeg je kod oštećenog nastupila navedena laka telesna povreda.

(Presuda Okružnog suda u Subotici Kž. 351/08 od 16. 9. 2008). ${ }^{2}$

Dakle, iz citirane odluke proizilazi da ako dođe do fizičkog napada ili do fizičkog obračuna sa učesnicima sportske priredbe, nije nužno i postojanje lake telesne povrede kod oštećenog lica. U krivičnom delu iz čl. 20. i to kako krivičnom delu predviđeno u Zakonu o sprečavanju... iz 2003. god. i iz 2007.

${ }^{2}$ Izbor sudske prakse, br. 12/08, str. 37. i 38. 
god., a za stav 1. nije nužno postojanje lakih telesnih povreda kod oštećenog lica da bi navedeno krivično delo postojalo, pa čak i kada se na sportski teren, sportski objekat unesu predmeti, pirotehnička sredstva ili druge eksplozivne, zapaljive, škodljive supstance, ne traži se da je usled njihove upotrebe nastala laka telesna povreda kod oštećenog lica, već samo da ,isti mogu da izazovu telesne povrede ili ugroze zdravlje učesnika sportske priredbe".

- „Okrivljeni je na fudbalskoj utakmici, u nameri da izazove nasilje bacio stolicu prema zaštitnoj ogradi, ka terenu u pravcu pripadnika žandarmerije. Ovakve radnje su pravilno kvalifikovane kao krivično delo nasilničko ponašanje na sportskoj priredbi iz čl. 20. st. 1. Zakona o sprečavanju nasilja i nedoličnog ponašanja na sportskim priredbama."

(Presuda Okružnog suda u Beogradu Kž.1767/06 od 28. 6. 2006. g. i presuda Drugog opštinskog suda u Beogradu K.776/05 od 21. 6. 2005. g.). ${ }^{3}$

Zaštitni objekat krivičnog dela nasilničko ponašanje na sportskoj priredbi, nije život i telo pojedinca koji prisustvuju sportskoj priredbi, već je sigurnost $i$ bezbednost svih učesnika sportske priredbe od nasilja kojem bi svi učesnici sportske priredbe mogli biti izloženi. Utvrđena činjenica da je oštećeni u kritičnom događaju zadobio laku telesnu povredu u vidu posekotine u predelu čela, nije od značaja za ovakvu odluku drugostepenog suda, jer zaštitni objekat krivičnog dela predviđeno u čl. 20. st. 1. Zakona o sprečavanju nasilja i nedoličnog ponašanja na sportskim priredbama nije život i telo pojedinaca koji prisustvuju sportskoj priredbi, već je to sigurnost i bezbednost svih učesnika sportske priredbe, zaštita od nasilja kojem bi svi učesnici sportske priredbe mogli biti izloženi, te se u tom pogledu ovo kriv. delo razlikuje od kriv. dela protiv života i tela.

(Presuda Okružnog suda u Beogradu Kž.3401/06 od 14. 2. 2007. god. i presuda Opštinskog suda u Obrenovcu K.205/05 od 13. 4. 2006. g.). ${ }^{4}$

- „Okrivljeni je izvršio ovo krivično delo - krivično delo iz čl. 20. st. 1. Zakona o sprečavanju nasilja i nedolično ponašanje na sportskim priredbama kada je u toku fudbalske utakmice lomio stolice i tako odlomljene predmete bacao na sportski teren."

(Presuda Okružnog suda u Beogradu Kž.2802/05 od 10. 11. 2005. g. i presuda Drugog opštinskog suda u Beogradu K.240/05 od 30. 6. 2005. g.). ${ }^{5}$

- „Učinilac je fizički napao učesnika sportske priredbe na taj način što se kao trener košarkaškog kluba koji je bio diskvalifikovan zbog čega je trebao da napusti teren i sportsku halu, vratio na teren i sudiju udario

${ }^{3}$ Zbirka sudskih odluka iz krivične materije, Ilija Simić, str. 66.

${ }^{4}$ Zbirka sudskih odluka iz krivične materije, Ilija Simić, str. 237.

${ }^{5}$ Zbirka sudskih odluka iz krivične materije, Ilija Simić, str. 204. 
stolicom. Okrivljeni je oglašen krivim zbog krivičnog dela nasilničko ponašanje na sportskoj priredbi iz čl. 20. st. 1. Zakona o sprečavanju nasilja i nedoličnog ponašanja na sportskim priredbama izvršenog u sticaju sa krivičnim delom lake telesne povrede.”

Okrivljeni je kao trener KK za vreme utakmice koju je igrao njegov tim u sportskoj hali zbog prigovora sudiji diskvalifikovan, zbog čega je bio dužan da napusti teren i salu, vratio se na teret i nakon kraće rasprave udario stolicom sudiju, usled čega je ovaj zadobio lake telesne povrede. Ovakve utvrđene radnje pravilno su kvalifikovane kao fizički napad na učesnika sportske priredbe što predstavlja krivično delo nasilničko ponašanje na sportskoj priredbi iz čl. 20. st. 1. Zakona o sprečavanju nasilja i nedoličnog ponašanja na sportskim priredbama.

(Presuda Okružnog suda u Beogradu Kž.32/06 od 31. 1. 2006. g. i presuda Četvrtog opštinskog suda u Beogradu K.62/05 od 8. 11. 2005. g.). ${ }^{6}$

Ukazujemo na karakterističan sadržaj ove odluke koja daje objašnjenje samo u delu fizičkog napada na učesnika sportske priredbe a ne i zašto je okrivljeni izvršio u sticaju i krivično delo lake telesne povrede, a sve ovo radi upoređenja sa ranije citiranom odlukom Okružnog suda u Subotici.

- „Okrivljeni u nameri da izazove nasilje, bacio je na sportski teren pirotehničko sredstvo koje može da izazove telesne povrede i ugrozi zdravlje učesnika sportske priredbe, tako što je na finalnoj utakmici fudbalskog kupa zapalio i bacio baklju na teren."

(Rešenje Okružnog suda u Beogradu Kž.2450/06 od 2. 10. 2006. g. i rešenje Drugog opštinskog suda u Beogradu K.1434/05 od 20. 4. 2006. g.). ${ }^{7}$

U pitanju je sudska odluka koja se odnosi na događaj između 2003. g. i 2007. g. pa je primenjen čl. 20. Zakona o sprečavanju... iz 2007. g. koji je imao odredbu ,ko u nameri da izazove nasilje”.

„Kada okrivljeni na fudbalskoj utakmici sa tribina na sportski teren baci polomljenu stolicu, ovakvom svojom radnjom se nedolično ponašao pa je time izvršio krivično delo iz čl. 20. Zakona o sprečavanju nasilja i nedoličnog ponašanja na sportskim priredbama."

(Presuda Okružnog suda u Beogradu Kž.2325/06 od 12. 9. 2006. g. i presuda Drugog opštinskog suda u Beogradu K.1730/05 od 7. 4. 2006. g.). ${ }^{8}$

- „Krivično delo nasilničko ponašanje na sportskim priredbama mogu izvršiti i igrači na terenu". Prvostepenom presudom više okrivljenih je oglašeno krivim da su na sportskoj priredbi, košarkaškoj utakmici

\footnotetext{
${ }^{6}$ Intermeks - Sudska praksa - kompletan tekst sudske odluke.

${ }^{7}$ Intermeks - Sudska praksa - kompletan tekst sudske odluke.

${ }^{8}$ Intermeks - Sudska praksa - kompletan tekst sudske odluke.
} 
između dva košarkaška tima nakon prekida igre zbog prekršaja nad igračem jednog tima, učestvovali u fizičkom obračunu između igrača. Četiri okrivljena su igrači jednog od košarkaških timova koji su se zatekli na terenu u momentu sviranja prekida, dok su dva okrivljena utrčala u teren sa klupe a preostali okrivljeni su sa tribina ušli u teren."

(Presuda Okružnog suda u Beogradu Kž.2783/06 od 10. 11. 2006. god. i presuda Prvog opštinskog suda u Beogradu K.2338/05 od 18. 4. 2006. g.). ${ }^{9}$

Dakle, igrač na terenu je u smislu odredbe čl. 2. st. 4. Zakona o sprečavanju nasilja... učesik sportske priredbe jer je prisutan na sportskoj priredbi. Bliže objašnjenje igrača kao učesnika sportske priredbe sadrži sledeća sudska odluka:

- „Izvršilac krivičnog dela nasilničko ponašanje na sportskoj priredbi iz čl. 20. st. 1. Zakona o sprečavanju nasilja i nedoličnog ponašanja na sportskoj priredbi može biti i aktivni učesnik - igrač sportske priredbe."

Presudom prvostepenog suda okrivljeni su oglašeni krivim zbog navedenog krivičnog dela a presudom drugostepenog suda preinačena je prvostepena presuda u delu odluke o kaznama, a u ostalim delovima žalba okrivljenih se odbija kao neosnovana. Pravilnom ocenom odbrane okrivljenih i svih izvedenih dokaza nesumnjivo proizilazi da su okrivljeni kao igrači FK... u vreme i na mestu označenom u izreci presude izazvali nasilje na taj način što je okrivljeni posle dosuđenog penala za protivničku ekipu, fizički napao glavnog sudiju i udario ga rukom u predeo leđa psujući mu majku, posle čega je drugookrivljeni glavnog sudiju loptom gađao u glavu. Ovakvo činjenično stanje je nesumnjivo utvrđeno iz iskaza svedoka - glavnog sudije na utakmici, kao i svedoka koji je pomoćnik glavnog sudije, a takođe i iz zapisnika i izveštaja zvaničnih lica fudbalskog saveza sa pomenute utakmice. Pravilno je prvostepeni sud radnje okrivljenih kvalifikovao po čl. 20. st. 1. pomenutog zakona u čemu su dati potpuni i jasni razlozi, pa su navodi u žalbi neosnovani. Navod žalbe branilaca okrivljenih da izvršilac ovog krivičnog dela ne može biti igrač - učesnik sportske priredbe, već samo gledalac ili neko treće lice je neosnovan, s obzirom da se kao izvršilac ovog krivičnog dela mogu pojaviti svi oni koji na sportskim priredbama izazivaju nasilje, fizički napadaju ili obračunavaju se sa učesnicima sportskih priredbi. Dakle, izvršilac krivičnog dela može biti i aktivni učesnik - igrač fudbalske utakmice koji učini radnju koja je propisana kao ovo krivično delo.

(Presuda Opštinskog suda u Čačku K.264/06 od 31. 12. 2007. g. i presuda Okružnog suda u Čačku Kž.137/08 od 19. 3. 2008. g.). ${ }^{10}$

\footnotetext{
${ }^{9}$ Intermeks - Sudska praksa - kompletan tekst sudske odluke.

${ }^{10}$ Sudska praksa, br. 2/09, str. 17.
} 
- „Svaka krivično-pravna radnja pobrojana u opisu krivičnog dela treba da bude izvršena u nameri da se izazove nasilje”. Biće krivičnog dela iz čl. 20. st. 1. Zakona o sprečavanju nasilja i nedoličnog ponašanja na sportskim priredbama sastoji se iz više alternativno propisanih krivično-pravnih radnji, koje učinilac mora učiniti kao pripadnik grupe, ali sve alternativno propisane radnje izvršenja kao objektivni elementi ovog krivičnog dela moraju biti od strane učinioca izvršene u nameri da izazovu nasilje. Namera učinioca da izazove nasilje kao subjektivni elemenat bića ovog krivičnog dela izričito je propisana odredba čl. 20. ovog zakona, a proizilazi i iz razloga donošenja zakona jer zaštitni objekat ovog krivičnog dela nije život i telo pojedinca koji prisustvuje sportskoj priredbi, već je to sigurnost i bezbednost svih učesnika sportske priredbe od nasilja kojim bi svi učesnici sportske priredbe mogli biti izloženi te se u tom pogledu ovo krivično delo razlikuje od krivičnih dela protiv života i tela."

(Rešenje Okružnog suda u Beogradu Kž.2755/06 od 28. 2. 2007. g.). ${ }^{11}$

Ova odluka objašnjava „nameru” kao bitan elemenat krivičnog dela koji je postojao do izmene zakona iz 2007.god. kao i pojam zaštitnog objekta toga krivičnog dela.

- „Žalbom javnog tužioca se posebno ističe da iz sadržine izvedenih dokaza proizilazi da je okrivljeni kritičnom prilikom učestvovao u fizičkom obračunu na sportskoj priredbi što inače ne spori ni okrivljeni kao i drugi saslušani svedoci, pa je ostalo nejasno iz kojih razloga prvostepeni sud tu odlučnu činjenicu ne uzima kao dokazanu, a ista je sasvim dovoljna za postojanje predmetnog krivičnog dela iz akta javne optužnice."

„Prema naloženju Okružnog suda za kvalifikaciju krivičnog dela iz čl. 20. st. 1. Zakona o sprečavanju nasilja i nedoličnog ponašanja na sportskim priredbama, nije nužno i neophodno da je nekom licu naneta telesna povreda, već je dovoljno da je takvo lice fizički napadnuto, pa je u konkretnom slučaju za postojanje dela u odnosu na okrivljenog sasvim dovoljna činjenica da je isti kritičnom prilikom kao učesnik u sportskoj priredbi učestvovao u fizičkom obračunu, čak i u situaciji kada nije dokazano da je okrivljeni oštećenom naneo opisanu laku telesnu povredu".

(Rešenje Okružnog suda u Subotici Kž.622/08 od 6. 2. 2009. g.). ${ }^{12}$

Iz ove odluke proizilazi nepravilan stav prvostepenog suda, da iako je došlo do fizičkog obračuna sa učesnikom sportske priredbe, a nije došlo do

\footnotetext{
${ }^{11}$ Paragraf - sudske odluke.

${ }^{12}$ Paragraf - sudske odluke.
} 
nanošenja telesnih povreda, tada nije dokazano da je okrivljeni izvršio navedeno krivično delo.

Navešćemo dva karakteristična slučaja Višeg suda u Čačku.

- Presudom Višeg suda u Čačku K.14/10 od 6. 4. 2010. g., a koja je pravnosnažna, okrivljeni je proglašen krivim zbog krivičnog dela nasilničko ponašanje na sportskoj priredbi iz čl. 344a st. 1. KZ, a u izreci je navedeno što se fizički obračunavao sa glavnim sudijom... na taj način što mu je zadao dva udarca u predeo grudi, zbog čega mu je oštećeni dosudio crveni karton i uputio ga prema klupi delegata nakon čega je okrivljeni prišao oštećenom sa leđa i zadao mu udarac nogom u predeo zadnjice kada je intervenisala lekarska služba koja je optuženog udaljila. ${ }^{13}$

- Presudom Višeg suda u Čačku K.32/10 od 24. 8. 2010. g. a koja je pravnosnažna, okrivljeni je proglašen krivim zbog krivičnog dela čl. 20. st. 1. Zakona o sprečavanju nasilja..., a u izreci je navedeno da je na sportski teren uneo pirotehnička sredstva i to 100 komada petardi uvezanih i upakovanih u celofan kao i jedan nož na otvaranje - tzv. leptir koji je držao u svom rancu dok je trajala navedena fudbalska utakmica. $^{14}$

Treba dodati da je Zakonom o izmenama i dopunama Krivičnog zakonika (Službeni glasnik RS br. 111 od 29. 12. 2009.g.) a u čl. 3. je navedeno da se posle čl. 89a KZ dodaje novi član 89b i naslov ,zabrana prisustvovanja određenim sportskim priredbama". Dakle radi se o novoj meri bezbednosti a čija svrha je i obuhvaćena članom 78. KZ. Kada je reč o primeni i izricanju pomenute mere bezbednosti treba primeniti odredbu čl. 78. KZ, a to znači da ima mesta izricanju iste radi otklanjanja stanja ili uslovi koji mogu biti od uticaja da učinilac u buduće ne vrši krivična dela kao i odredbu čl. 89b st. 1 . KZ koja se odnosi na zaštitu opšte bezbednosti. Inače, navedena mera bezbednosti se može izreći učiniocu svakog krivičnog dela, ali naravno uz ostvarenje uslova da je potrebno radi zaštite opšte bezbednosti, a što se mora utvrđivati u svakom konkretnom slučaju.

${ }^{13}$ Pravnosnažna presuda Višeg suda u Čačku K.14/10 od 6. 4. 2010. god., arhiva Višeg javnog tužilaštva u Čačku.

${ }_{14}$ Pravnosnažna presuda Višeg suda u Čačku K.32/10 od 24. 8. 2010. god., arhiva Višeg javnog tužilaštva u Čačku. 